\title{
大規模水中構造物に適用する水中不分離性コンクリートの研究 \\ THE STUDY OF UNTIWASHOUT UNDERWATER CONCRETE FOR LARGE UNDERWATER STRUCTURES
}

\author{
平野 茂*・中川良隆**・中平 淳***・大友 \\ 健**** \\ By Shigeru HIRANO, Yoshitaka NAKAGAWA, Jun NAKAHIRA and Takeshi OHTOMO
}

\begin{abstract}
Antiwashout underwater concrete is recently used due to the demand for speedy marine construction work of large structures.

Antiwashout underwater concrete was also used for the construction of foundation for the main towers of the Akashi Kaikyo Bridge and its excellent properties have been verified. The antiwashout underwater concrete, for large-scale pouring, must retain its consistency for long hours, have low heat of hydration and stable placing properties.

This study clarifies the effect of aggregate, sand, cement, and admixture on the flowability and setting time of concrete, and a better mixing method was developed to improve the quality of the antiwashout underwater concrete.
\end{abstract}

Keywords : antiwashout underwater concrete, admixture, flowability

\section{1. 序論}

水中不分離性コンクリートは，混和剤として混入した 粘調剂の作用によりコンクリートの構成材料が粘着さ れ，フレッシュコンクリートの状態で周りの水から洗い 作用を受けても分離しにくい特性をもっている．また， セルフレベリング性より，自重で平滑に仕上がる特性を もっている.

近年，わが国における建設工事の大型化，大深度化， 急速化および合理化の要請から，水中コンクリートが多 量に使用されるようになり，特に水中不分離性コンク リートは，その優れた特性，信頼性により明石海峡大橋 主塔基礎等重要な大規模水中構造物に使用されている.

明石海峡大橋主塔基礎の上うな大規模水中構造物を， 水中不分離性コンクリートにより施工する場合，一般の 構造物と大きく異なるのは以下の点である.

* 正会員 本州四国連絡橋公団垂水工事事務所技術課長

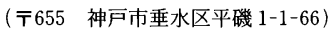

** 正会員 明石海峡大橋 $3 \mathrm{P}$ 下部工大成・間 - 佐藤 - 東 洋・日本国土共同企業体所長（６55 神戸市垂水区平磯 3-1-50)

*** 正会員 明石海峡大橋 $3 \mathrm{P}$ 下部工大成 - 間 - 佐藤 - 東 洋・日本国土共同企業体 (同上)

**** 正会員 大成建設 (株) 技術研究所（２２45 横浜市戸塚区 名瀬町 344-1)
(1) 広い面積を限られた数の打設管で打設するため, コンクリートに長距離流動性が要求される.

（2）マスコンクリートとなるため，セメントの水和熱 による温度応力が問題となる。

（3）多量のコンクリートを安定した品質で製造，打設 する設備が必要なこと.

一般に水中コンクリートを大規模打設する場合，a) 高流動性（大きなスランプフローをもつ，たとえばスラ ンプフロー $50 \mathrm{~cm}$ 以上）のコンクリートを，b) 短時間 で打設することが望ましい。しかし，水中不分離性コン クリートに高流動性を具備させるために, 単位水量を大 きくしていくと, 分離抵抗性, 強度の問題が発生する.

この問題を克服するには, 水中不分離性混和剂量, 七 メント量を増やせば良いが，その場合(2)の問題が発生す る.したがってセメントの低発熱化，プレクーリングの 実施が必要となる.

一方，多量のコンクリートを短時間に打設するには， コンクリートの製造，打設設備を大規模にする必要があ り，経済性の面から制限がある。そこで，コンクリート を長い時間を掛けて (製造, 圧送能力の制限), 長距離 流動（打設設備の数の制限）させる必要がある. すなわ ち(1)の問題が発生する. したがってコンクリートは長時 間の流動性の保持, 流動に伴う材料分離, 品質変動が少 
ないことが要求される.

また，実施工においては(3)に示すように安定した品質 のコンクリートを製造，打設できる設備を作る必要があ る.

本研究の目的は以上の問題点を解決することにあり, 具体的には以下の 2 点である.

(a) 低発熱, 混合セメントを使用した水中不分離性コ ンクリートの流動性, 凝結等の性質に及ぼす構成材 料および配合の影響を明らかにする。

(b) 水中不分離性コンクリートは, 水中不分離性混和 剂を分散させるため, 通常, 空練りをするので普通 コンクリートよりも練りまぜ時間が長い。また，こ の際，骨材に表面水がある場合，団粒状になり練上 りコンクリートの品質が安定しないことがある．し たがって，練りまぜ時間が短く安定した品質のコン クリートが製造できる新しい練りまぜ方法の開発.

本研究に対応する既往の研究としては, 水中不分離性 コンクリートの流動性について田沢ら ${ }^{11}$ が，練上りスラ ンプフローに及ぼすコンクリート構成材料の影響につい て検討をしている。しかし，流動性の長時間保持および 凝結の関係についての研究は，なされていない。

練りまぜ方法については，松井ら ${ }^{2)}$ が連続練りミキ サーで水中不分離性混和剂のプレミックスセメントが有 効であること，および，宮野ら ${ }^{3)}$ がベースコンクリート への水中不分離性混和剂, 流動化剂の添加時期によりフ レッシュコンクリートの性状があまり変化しないことを 明らかにしている，しかし，練りまぜ方法による品質の 変動について十分検討されているわけではない.

ここでは本研究の成果をもとに施工した明石海峡大橋 $3 \mathrm{P}$ 主塔基礎の水中コンクリート工事についても紹介 する.

\section{2. 水中不分離性コンクリートの品質に関する 研究}

\section{(1) 概 要}

水中不分離性混和剂として水溶性セルロースエーテル を使用する水中不分離性コンクリートは凝結遅延するこ とが知られている. 水溶性セルロースエーテルは非イオ ン性で一般にメチルセルロース（以下 MC と略す）と よばれている．図一1に分子式を示す．分子の平均的長 さは約 $1 \mu \mathrm{m}$, 太さは約 $0.001 \mu \mathrm{m}$ の長鎖状高分子で, セ メント粒子等に吸着するとともに，粒子間隙に存在し， 水溶液粘度を高めるものと考えられている。この粘性と 凝結遅延性が流動性の長時間保持をもたらしていると考 えられる. MC の存在により練りまぜ時の材料の投入 順序，練りまぜ時間が，コンクリートの品質に大きく影 響する. 水中不分離性コンクリートの以上の特徴をろま

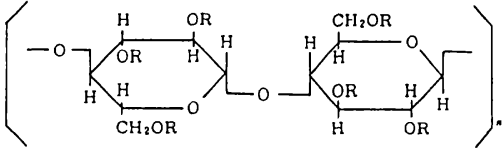

図一1セルロース系水中不分離性混和剤の化学構造式

表一1 水中不分離性コンクリートの現場配合および要求品質

\begin{tabular}{|c|c|c|c|c|c|c|c|c|c|}
\hline \multirow{2}{*}{ 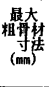 } & \multirow{2}{*}{$\begin{array}{c}\text { 結沓忉 } \\
(\%) \\
(\%)\end{array}$} & \multirow{2}{*}{$\begin{array}{c}\text { 綊搰材 } \\
\text { 西 } \\
\text { (\%) }\end{array}$} & \multicolumn{5}{|c|}{ 単 位 $\left(\mathrm{kg} / \mathrm{m}^{\prime}\right)$} & \multicolumn{2}{|c|}{ 単位 $\left(\ell / \mathrm{m}^{\prime}\right)$} \\
\hline & & & 水 & 結合仏 & 細得记 & 粗骨材 & 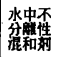 & 流整化 & $\underset{\text { 证水新 }}{\mathrm{AE}}$ \\
\hline 20 & 67 & 40 & 213 & 320 & 648 & 1006 & 2.3 & 標竨量 & 相部量 \\
\hline
\end{tabular}

\section{表一2＼cjkstart検討項目および実験内容}

\begin{tabular}{|c|c|}
\hline 模 时 媔 目 & 内 \\
\hline \multicolumn{2}{|c|}{ 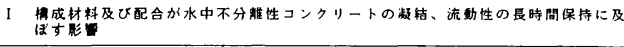 } \\
\hline 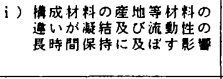 & 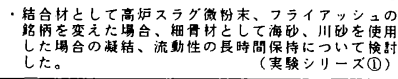 \\
\hline 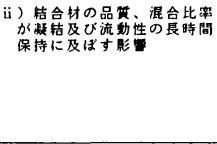 & 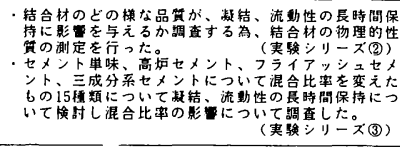 \\
\hline 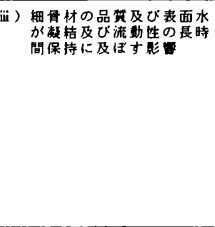 & 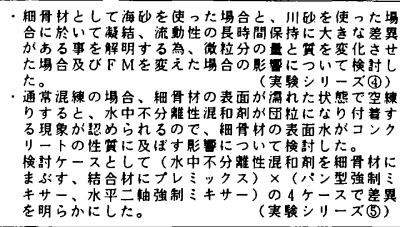 \\
\hline 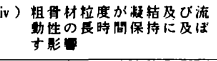 & 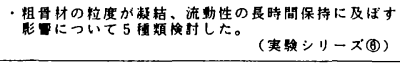 \\
\hline 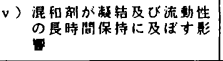 & 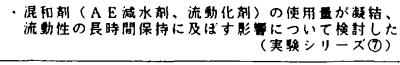 \\
\hline \multicolumn{2}{|c|}{ 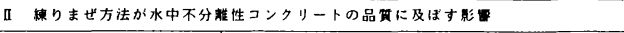 } \\
\hline vi）練りまぜ方法の影 & 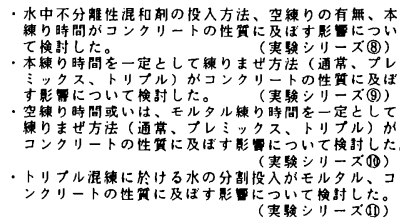 \\
\hline
\end{tabular}

え，序論で述べた@，(bについて検討した。

検討にあたり，大規模水中コンクリートに適用する水 中不分離性コンクリートの仕様例として, 明石海峡大橋 $3 \mathrm{P}$ 主塔基礎の水中コンクリートの現場配合と, 要求 品質を表一1に示す。

（2）実験内容

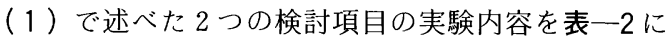
示す.また，それぞれの実験シリーズを表一3に示す.

ここで, 水中不分離性コンクリートの流動性はスラン プフローで評価する．すなわち，練上りの流動性は分離 しない範囲でスランプフローが大きい方が良い。流動性 の長時間保持はスランプフローの経時低下量が少ないの 
表一3実験シリーズ

\begin{tabular}{|c|c|c|c|c|c|c|c|c|c|c|c|c|c|c|c|c|c|c|}
\hline \multirow{2}{*}{\multicolumn{2}{|c|}{ 実糇要因 }} & \multirow{2}{*}{$\begin{array}{r}\text { 䊅合仏啋頪 } \\
* 1 \\
\end{array}$} & \multirow{2}{*}{ 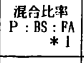 } & \multirow{2}{*}{\begin{tabular}{l|}
$W / C$ \\
$(x)$
\end{tabular}} & \multirow{2}{*}{\begin{tabular}{l|l} 
\\
S/a \\
\end{tabular}} & \multicolumn{2}{|c|}{ 果位 } & \multicolumn{2}{|c|}{$\left(\mathrm{kg} / \mathrm{m}^{3}\right)$} & \multirow{2}{*}{\begin{tabular}{l|l|}
$* 1$ \\
USCA \\
\end{tabular}} & \multicolumn{2}{|c|}{ 哩位 $(\mathrm{c} \times \mathrm{x})$} & \multicolumn{4}{|c|}{ 楝りまぜ方法 ミ3 } & \multirow{2}{*}{$\begin{array}{r}+2 \\
\vdots\end{array}$} & \multirow{2}{*}{ 增 要 } \\
\hline & & & & & & $\mathrm{C}$ & $w$ & $\mathrm{~s}$ & G & & S.P. A & Eadt & 方法 & USCA & 孛練り & 木㙌り & & \\
\hline \multicolumn{2}{|c|}{ 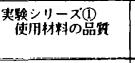 } & $\begin{array}{l}\text { OP0 } \\
\text { IIS- } a, \text { BS-b } \\
\text { FA A, FA-B } \\
\end{array}$ & $30: 40: 30$ & 65 & 40 & 328 & 213 & 635 & 984 & 2.5 & 1.0 & $0.25 \mid$ & 通营 & 捗混入 & $60 \mathrm{~s}$ & 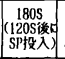 & パン & 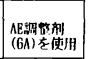 \\
\hline \multicolumn{2}{|c|}{ 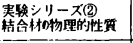 } & & & & & & & & & & & & & & & & & 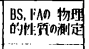 \\
\hline \multicolumn{2}{|c|}{ 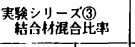 } & MP6:BS6:FA6 & 15棈頪 & 65 & 40 & 320 & 208 & $\begin{array}{c}645 \sim \\
673\end{array}$ & $\begin{array}{l}10022 \\
1044 \\
\end{array}$ & 2.3 & 1.0 & 0.125 & トリト & ルミラス & & $\begin{array}{c}(255) \\
155\end{array}$ & 二 湅 & 1次水得0.8 \\
\hline \multirow{3}{*}{ 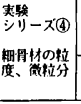 } & \multirow{2}{*}{\begin{tabular}{ll|} 
(a) & \\
柆 & 度 \\
\end{tabular}} & MP1:BS3:FAI & $30: 40: 30$ & 68 & 40 & 320 & 219 & 610 & 982 & 2.3 & 1.0 & 0.25 & 通掌 & 硙混人 & 30 s & 905 & 二 扒 & \\
\hline & & MPA:BS5:PA G & $25: 40: 35$ & 65 & 40 & 320 & 208 & 650 & 1021 & 2.3 & 1.0 & 0.15 & $11+n$ & A:YIR & 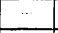 & $\begin{array}{l}(255) \\
455\end{array}$ & 二蚰 & 次水界 0.8 \\
\hline & 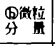 & OPO:BSa:FA A & $30: 40: 30$ & 65 & 40 & 328 & 213 & 6.36 & 991 & 2.5 & 1.0 & 0.25 & 通莹 & 础误人 & $60 \mathrm{~S}$ & $180 \mathrm{~S}$ & バン & 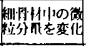 \\
\hline \multirow{2}{*}{\multicolumn{2}{|c|}{ 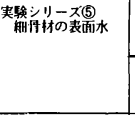 }} & MPI : BSI :FAI & $27: 40: 33$ & 66 & 10 & 320 & 210 & 640 & 994 & 2.3 & 1.0 & 0.25 & \begin{tabular}{|l|} 
通常 \\
ルミククス \\
\end{tabular} & 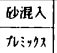 & 605 & $120 \mathrm{~S}$ & バン & \\
\hline & & MPI : BS3:FAI & $30: 40: 30$ & 68 & 10 & 320 & 219 & 610 & 982 & 2.3 & 1.0 & 0.25 & 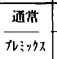 & 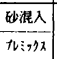 & $30 \mathrm{~S}$ & $90 \mathrm{~s}$ & 二 㠹 & \\
\hline \multicolumn{2}{|c|}{ 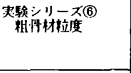 } & MPG: BS6:FA6 & $25: 45: 30$ & 65 & 40 & 320 & 208 & 650 & 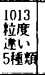 & 2.3 & 1.0 & 0.125 & $1 n+1$ & $x: y>x$ & & $\begin{array}{l}\text { (25S) } \\
155\end{array}$ & 二 & 次水而0.8 \\
\hline \multicolumn{2}{|c|}{ 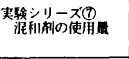 } & MPI:BSI:FAI & $27: 40: 33$ & 66 & 40 & 320 & 210 & 610 & 994 & $2.3 \mathrm{p}$ & \begin{tabular}{r|r}
0.1 .0 \\
2.0
\end{tabular} & $\begin{array}{l}0.0 \\
\sim 0.4 \\
\end{array}$ & 通堂 & 秘混人 & $60 \mathrm{~S}$ & $120 \mathrm{~S}$ & バン & \\
\hline \multirow{2}{*}{\multicolumn{2}{|c|}{ 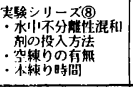 }} & MPI: :BS3:FAI & $30: 40: 30$ & 68 & 40 & 320 & 219 & 630 & 984 & 2.3 & 1.0 & 0.25 & $\pi: y, x$ & A & 0. $\quad 15 s$ & 25^90s & & \\
\hline & & & & & & & & & & & & & 通堂 & 称紸入 & $0.15 \mathrm{~S}$ & $25 \times 905$ & 二甠 & \\
\hline \multirow{3}{*}{\multicolumn{2}{|c|}{ 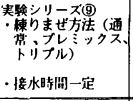 }} & OPI : BS3:FAI & $20: 50: 30$ & 67 & 40 & 320 & 215 & $6: 33$ & 990 & 2.3 & 1.0 & 0.25 & 通营 & 訬混入 & $15 S$ & $75 \mathrm{~S}$ & 他 & \\
\hline & & & & & & & & & & & & & k: & 九ミックス & 0 & $75 S$ & 等 & \\
\hline & & & & & & & & & & & & & $ト \| ナ n$ & ル:ワクス & - & $\begin{array}{l}(30 S) \\
45 S \\
\end{array}$ & & $\begin{array}{l}1 \text { 次水高 } \\
0.8 \sim 1.0\end{array}$ \\
\hline \multirow{3}{*}{\multicolumn{2}{|c|}{ 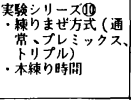 }} & PI:AS3:FAI & $20: 50: 30$ & 67 & 10 & 320 & 215 & 633 & 990 & 2.3 & 1.00 & 0.25 & 通 常 & 仙注入 & 30 & 25-90s & $\therefore$ 妯 & \\
\hline & & דול. & 20.000 .00 & (1) & & 000 & 201 & & & & & & A: & A & 0 & $25 \sim 75 \mathrm{~S}$ & & \\
\hline & & & & & & & & & & & & & 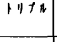 & Aミクス & - & $\begin{array}{r}(30 S) \\
25 \sim 75 S \\
\end{array}$ & & 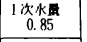 \\
\hline \multirow{2}{*}{\multicolumn{2}{|c|}{ 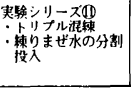 }} & MPI: US5:FA G & $25: 40: 35$ & 65 & 10 & 320 & 208 & \begin{tabular}{l|l}
650 & 1 \\
\end{tabular} & 1021 & 2.3 & 1.0 & 0.15 & \multirow{2}{*}{$1 n+n$} & \multirow{2}{*}{ f } & \multirow{2}{*}{-} & $\begin{array}{c}(255) \\
455\end{array}$ & \multirow[t]{2}{*}{ 二㫑 } & 1次水耑 \\
\hline & & & & 66.9 & -- & 505 & 338 & 1074 & - & 4.61 & 0 & 0 & & & & $\begin{array}{c}(35 S) \\
55 S\end{array}$ & & \\
\hline *1 & & $2 x+3$ & 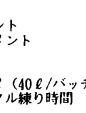 & & & & & $e$ & & & $\begin{array}{l}\text { G } \\
\text { USCA } \\
\text { S.P. } \\
\text { AE. }\end{array}$ & 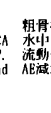 & 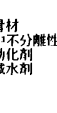 & 和敖 & & & & \\
\hline
\end{tabular}

(1) 通常混練

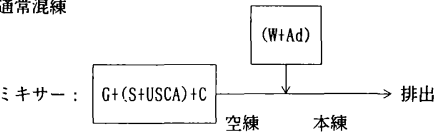

(2) イレミックス混練

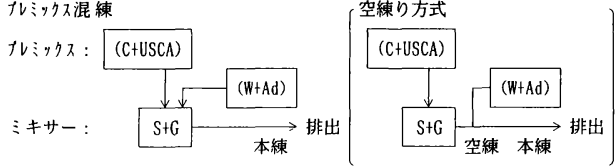

(3) トリプル混練

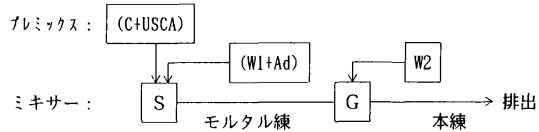

C : 結合材、U S C A : 水中不分離性混和材、S : 細骨材、G : 粗骨材

$\mathrm{W}:$ : 混練水、W 1 : 一次水、W 2 : 二次水、 $\mathrm{A} \mathrm{d}$ : 混和剤

図一2 水中不分離性コンクリートの練りまぜ方法

が良く, 8〜17 時間後の低下量で評価した。凝結特性に ついては, 凝結始発時間で評価し, 流動性の長時間保持 が得られる範囲で始発時間が早い方が良い。

\section{（3）練りまぜ方法および試験方法}

練りまぜ方法については，図一2に示す $3 つ$ 方法に
ついて実施した。

コンクリートの試験は主に，スランプフロー，凝結始 発時間，圧縮強度の測定を行い，その方法はJIS ある いは，水中不分離性コンクリートマニュアルによった。 コンクリート構成材料の物性試験は JIS によった。

\section{(4) 実験結果および考察}

a) 構成材料の産地等材料の違いが凝結および流動性 の長時間保持に及ぼす影響（実験シリーズ(1)）

結合材として，三成分系セメントを使用し，セメント のロット 2 種（表，図中では記号 OP 0, OP 2 で示す. 以下結合材の種類はすべて記号を用いる), 高炉スラグ 微粉末 2 種 $(\mathrm{a}, \mathrm{b})$ ，フライアッシュ 6 種 ( $\mathrm{A}, \mathrm{B}, \mathrm{C}$, $\mathrm{D}, \mathrm{E}, \mathrm{F})$ を組み合わせた 9 ケースの配合について，凝 結特性を調査した，各検討材料の組合せ，およびこれに よる水中不分離性コンクリートの凝結始発時間の測定值 を表一4 に示す。配合(1)〜9)の凝結始発時間は，使用す る材料の組合せにより 29.5〜 52.5 時間の間で変化して いる.

凝結始発時間に大きな差異を示したフライアッシュ $\mathrm{A}$ と $\mathrm{B}$, 海砂と川砂および参考として凝結始発時間で は大きな相違のない高炉スラグ微粉末 a と b のロット 違い $\left(a^{\prime}, b^{\prime}\right)\left(A^{\prime}, B^{\prime}\right)($ 海砂', 川砂') を使用して水中 
表一4 材料の組合せによる凝結始発時間の変化

\begin{tabular}{|c|c|c|c|c|c|}
\hline \multirow{2}{*}{ 配合番号 } & \multicolumn{4}{|c|}{ 材料の組合世 } & \multirow{2}{*}{$\begin{array}{c}\text { 凝結始登 } \\
\text { 間 } \\
\text { (hr) }\end{array}$} \\
\hline & C & BS & FA & $S$ & \\
\hline (1) & $\mathrm{OPO}$ & a & $A$ & 海眇 & 51.0 \\
\hline (2) & OP2 & a & $A$ & " & 38.0 \\
\hline (3) & OPO & $a$ & $B$ & $"$ & 32.5 \\
\hline (4) & OPO & $a$ & C & " & 52.5 \\
\hline (5) & OPO & a & D) & $"$ & 52.0 \\
\hline (6) & OPO & a & [) & " & 51.5 \\
\hline (7) & OPO & a & $\mathrm{F}$ & $"$ & 43.0 \\
\hline (8) & $\mathrm{OPO}$ & b & $A$ & $"$ & 47.5 \\
\hline (9) & OPO & a & $A$ & 川㫾 & 29.5 \\
\hline
\end{tabular}

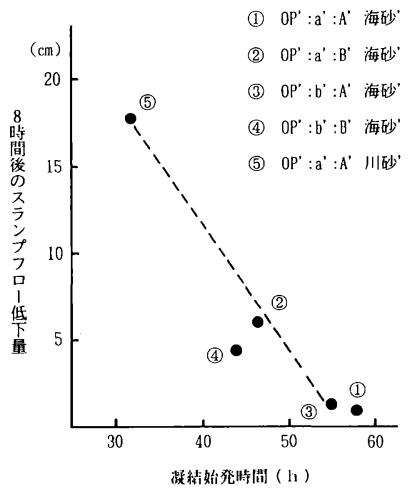

図一3 コンクリート構成材料の種類と凝結 流動性の長時間保持との関係
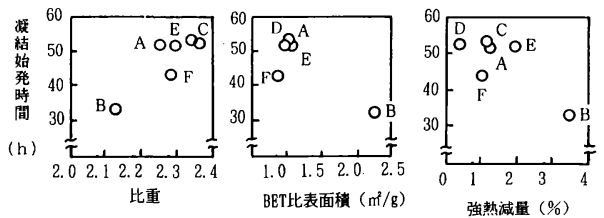

図一4 フライアッシュの物理的性質と凝結始発時間の関係

不分離性コンクリートの凝結始発時間, 練上りスランプ フローおよびスランプフローの経時変化を測定し, 凝結 特性と流動性の長時間保持の関係を検討した. その結果 を図一3に示す.

これらから, 凝結が早いものは流動性の長時間保持が 悪い傾向を示している.以上の結果より,特にフライアッ シュ, 細骨材の種類の違いにより, 凝結特性および流動 性の長時間保持性が大きく異なることが明らかである.

b) 結合材の品質, 混合比率が凝結および流動性の長 時間保持に及ぼす影響（実験シリーズ(2)）

(1) 結合材の品質について

(a) コンクリートとしたときに凝結遅延の程度を小さ くするフライアッシュ B は, 図一4に示すように比重 が小さく BET 比表面積, 強熱減量が大きい. 電子顕微 鏡による観察では，フライアッシュ B は，不定形で凸

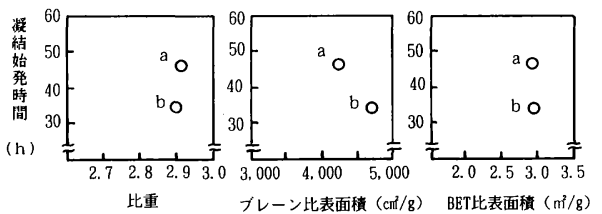

図—5 高炉スラグ微粉末の物理的性質と凝結始発時間の関係

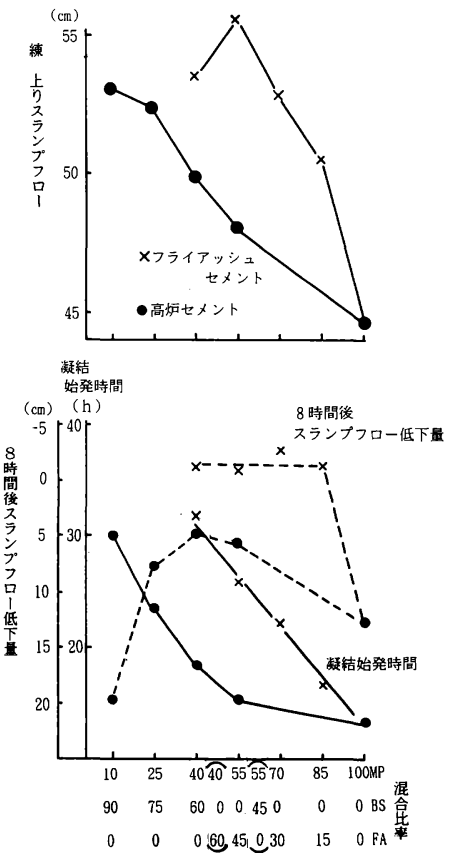

図一6 二成分系セメントの結合材の混合比率と 凝結，流動性の長時間保持の関係

凹がある粒子が多く，他のフライアッシュの SEM 像に みられる球状粒子の表面構造とは大きく異なっている.

(b) コンクリートとしたときに凝結遅延の程度が小さ くなる高炬スラグ微粉末 b は, 図一5 に示すように比重 および BET 比表面積は $\mathrm{a}$ と同等であるが，プレーン比 表面積は a よりも大きい．また，b はその形状が一様で はなく，ざらざらした表面を有しているのに対して，a は，形状がまるみを帯びており表面は滑らかになってい る.

(2) 結合材の混合比率について

(a) 二成分系混合セメント（実験シリーズ(3)）

図一6に示すように，二成分系混合セメントは (MP $: B S=10 ： 90)$ を除いてセメント単味に比較して, 練 上り時の流動性および流非性の長時間保持に優れてい る.フライアッシュ置換は高炬スラグ微粉末置換に比較 して同じ置換率の範囲では練上り時の流動性および流動 性の長時間保持に優れている。凝結始発時間は, 同じ置 換率の範囲ではフライアッシュ置換が高炉スラグ微粉末 置換より遅れる．また，両セメントとも置換率が大きく 


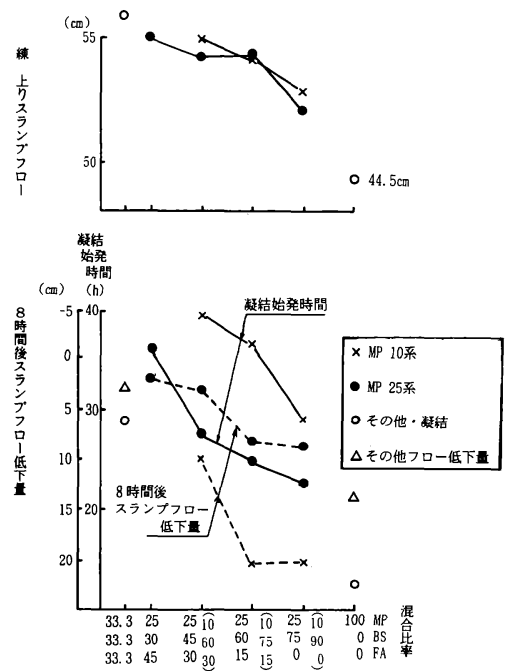

図一7 三成分系セメントの結合材の混合比率と 凝結, 流動性の長時間保持の関係
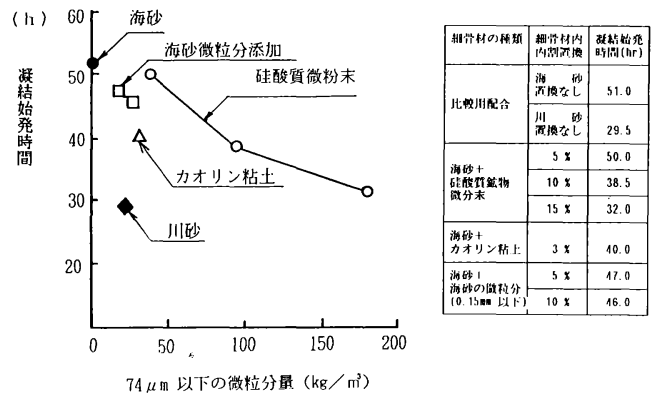

図一8 細骨材の微粒分量と凝結始発時間の関係

なるほど凝結始発時間は遅れる．練上り時流動性と流動 性の長時間保持には最適な置換率があり，実験範囲で， フライアッシュ置換は $45 \%$ ，高炬スラグ微粉末置換は $60 \%$ 程度の置換率が最適である.

(b) 三成分系混合セメント

図一7に示すように，三成分系混合セメントはセメン 卜単味に比較して, 練上り時の流動性および流動性の長 時間保持に優れている.

中庸熱ポルトランドセメントを $25 \%$ 混入した MP 25 系と $10 \%$ 混入した MP 10 系はフライアッシュ混入 比率が同じなら練上りの流動性はあまり変わらない。し かし，フライアッシュ混入比率が同じなら MP 25 系は MP 10 系に比較して流動性の長時間保持に優れており, かつ凝結始発時間が早い. 三成分系混合セメントは, フ ライアッシュ混入比率が大きくなるほど凝結始発時間が 遅れ, 流動性の長時間保持性が良くなる。

c）細骨材の品質および表面水が凝結および流動性の 長時間保持に及ぼす影響

(1) 細骨材の品質（実験シリーズ(4)）

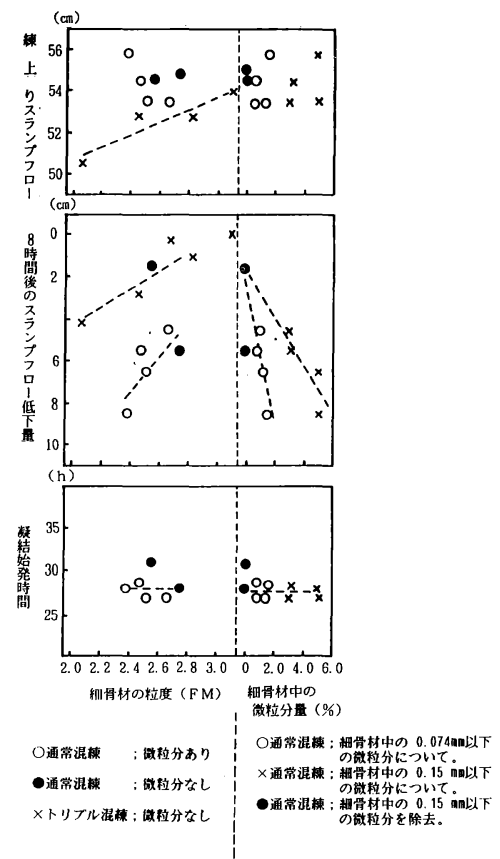

図一9細骨材の粒度および微粒分量がフレッシュ コンクリートの性質に及ぼす影響

実験(4)-(b)の結果を示した図一 8 より微粒分の量が多 くなるほよ゙, 凝結始発時間が早くなる傾向はよ゙の材料に ついてもみとめられるが，川砂を使用した場合が一番早 い. 粘土鉱物であるカオリンで置換すれば，少量で凝結 始発時間が早くなることから，凝結遅延の程度は混入す る鉱物の組成にも影響を受けるものと考えられる.

X 線回折による定性分析によれば，使用した海砂は 白雲母，石英が主体であるが，川砂には粘土鉱物である 緑泥石が含まれており，この影響により凝結が早くなつ ていることが考えられる. 細骨材が水中不分離性コンク リートの凝結特性に及ぼす影響については，物理的，化 学的の両面があるものと推察される.

図一9より FM が小さいほど，また細骨材中の微粒 分量が多いほどスランプフローの低下量が大きくなる傾 向が認められる.

凝結始発時間については, 細骨材中に含まれる微粒分 の量が多いほぼ凝結始発時間が早くなる傾向にあるが, この実験の範囲では, その差は 3 時間程度であり, 細骨 材の微粒分の及ぼす影響は，スランプフローの低下現象 に，より顕著に現われるものと考えられる.

(2) 細骨材の表面水の影響（実験シリーズ(5)）

図一10に示すように表面水のある細骨材に水中不分 離性混和剂をまぶして投入した場合は，表乾の細骨材の 場合に比較して練上りのスランプフローのばらつきが大 きく，スランプフローの低下量が大きい. 


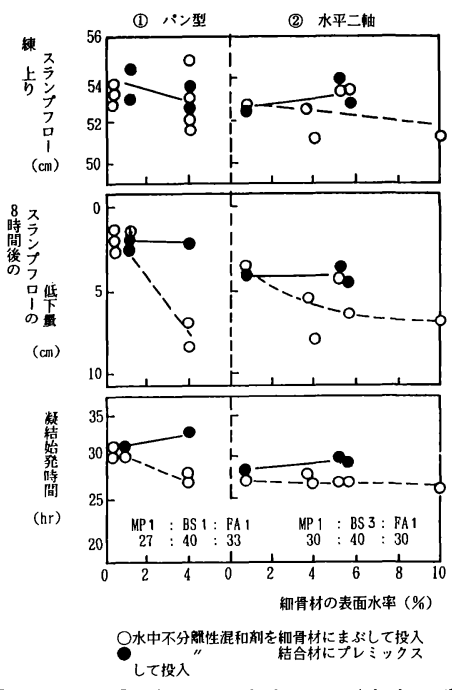

図一10 細骨材の表面水率および水中不分離 性混和剤の投入方法がフレッシュコ ンクリートの性質に及ぼす影響
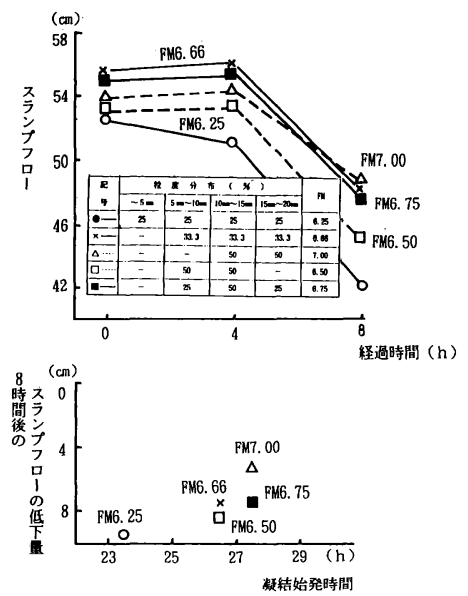

図一11粗骨材粒度と凝結始発時間, スランプフローの関係
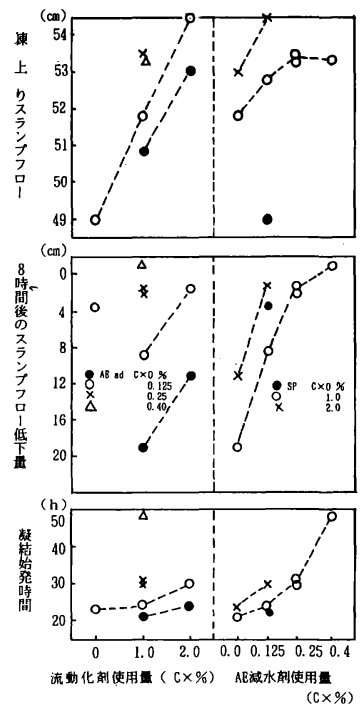

図一12 混和剤の使用量がフレッシュ コンクリートの特性に及ぼす 影䇾

水中不分離性混和剤を結合材にプレミックスして投入 した場合，スランプフロー，凝結始発時間に関して細骨 材の表面水の影響は少ない。したがって水中不分離性混 和剤を結合材にプレミックスする方法はコンクリートの 品質安定に有効である.

d）粗骨材粒度が凝結および流動性の長時間保持に及 ぼす影響（実験シリーズ(6)

図一11に示すように粗骨材粒度が細かいと練上りス ランプフローが小さく, スランプフローの長時間保持能 力が低く, 凝結始発時間が早い.

e）混和剤が凝結および流動性の長時間保持に及ぼす 影響（実験シリーズ7)

図一12 に示すように練上りスランプフローの改善に は流動化剤, スランプフローの長時間保持には $\mathrm{AE}$ 減 水剂が有効である.

スランプフローの長時間保持能力は $\mathrm{AE}$ 減水剤の使 用量が多くなるほど良くなるが, 凝結始発時間も遅くな る.

f）練りまぜ方法の影響

(1) 水中不分離性混和剤の投入方法と空練りの有無, 本練り時間がコンクリートの性質に及ぼす影響（実験シ リーズ8, 図一13参照)

\section{i) 通常混練}

空練りをしないと材料分離が生じる，すなわち，練上 り時の見掛けのスランプフローは大きくなる。これは水 中不分離性混和剂がコンクリート中に均等に分散しない ことにより，必要な増粘効果が得られないためと考えら れる.この場合水中不分離性混和剤が有効に作用してい ないのでスランプフローの低下量が大きくなる．また水
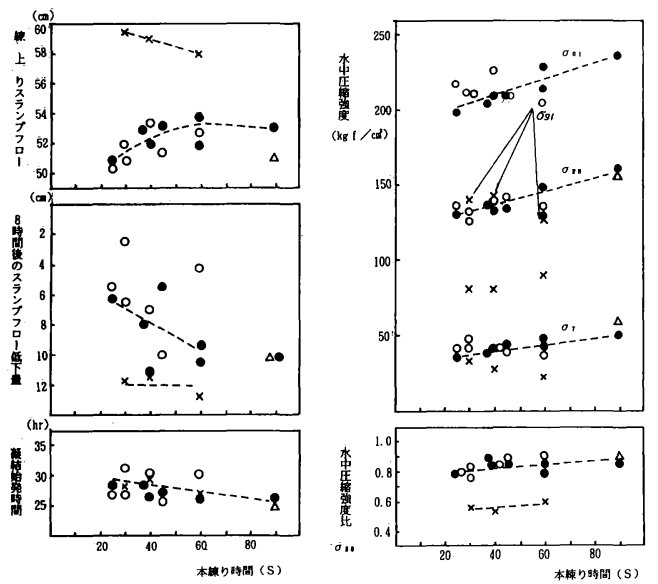

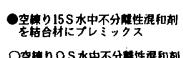

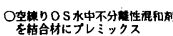

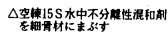

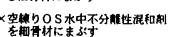

図一13練りまぜ時間および水中不分離性混和剤の投入方法が コンクリートの性質に及ぼす影響

中圧縮強度も小さくなる．練りまぜ時間を長くした場合 でも改善の傾向は認められない. 空練りを 15 秒程度で も行えばスランプフローの 8 時間後の低下量の改善は, 約 $2 \mathrm{~cm}$ 程度であるが, 水中圧縮強度および水中／気中 圧縮強度比が大幅に改善される。

ii）プレミックス混練

空練りをしなくても材料の分離は生じず, 空練りをし た場合とほぼ同様なフレッシュコンクリートの特性およ び強度となる．ただしバッチ間でのばらつきが空練りを したものに比較して若干大きい.

水中不分離性混和剤をプレミックスし空練りを実施し 
た場合，本練り時間とコンクリートの性質の間には次の 関係が認められる.

本練り時間を長くすると，

・練上りのスランプフローが大きくなる．ただし， 60 秒を過ぎると頭打ちとなる.

・スランプフローの低下量が大きくなる.

・凝結が促進される.

・強度が増進する。

iii）水中不分離性混和剤の投入方法の比較

c) の(2)でプレミックス混練は，細骨材に表面水のあ る場合, 通常混練に比較してスランプフローの長時間保 持が良いことを明らかにした。 また，図一13でプレミッ クス混練は若干ばらつきがあるが空練りをしなくても良 い品質のコンクリートが得られることを明らかにした.

したがって, プレミックス混練は通常混練より短い練 りまぜ時間で安定したコンクリートを作る可能性があ る.

(2) 練りまぜ方法 (通常, プレミックス, トリプル) がコンクリートの性質に及ぼす影響

i ) 接水後の練りまぜ時間（75 秒）を一定にした実 験(9)の結果を示した図一14からプレミックス混練およ びトリプル混練は通常混練に比較して練上りスランプフ ローが 1 2 cm 大きく, 8 時間後のスランプフローの低 下量は逆に 4 6 cm 小さいことがわかる. しかし, 水 中圧縮強度については, 練りまぜ方法による差異は少な いことから, 接水後の練りまぜ時間が一定の場合, 練り まぜ方法による影響は, スランプフローに及ぶものと思 われる.ここではトリプル混練が優れている.

ii）各練りまぜ方法で，練りまぜ時間を変化させた実 験10の結果を示した図一15から以下のことがわかる.

・練上りスランプフローは通常混練はばらつきが多 く, プレミックス混練では, 実験8図一13で示したの と同様, 本練り時間が長くなるとスランプフローの大き さは頭打ちの傾向がある. 一方, トリプル混練では, モ ルタル練り時間一定で, 本練り時間を変化させた $(\mathrm{A})$ および本練り時間一定で, モルタル練り時間を変化させ た（B）とも練りまぜ時間が長くなると練上りスランプ フローは大きくなる.この結果から，トリプル混練およ びプレミックス混練が通常混練に比較して優れていると いえる.

・スランプフローの長時間保持については, 10 時間 後のスランプフローの低下量で示すが, 通常混練では練 りまぜ時間とともに増大するが, プレミックス混練, 卜 リプル混練では減少している。この結果から，トリプル 混練および，プレミックス混練が通常混練に比較して優 れているといえる.

・凝結始発時間については, 通常混練では練りまぜ時

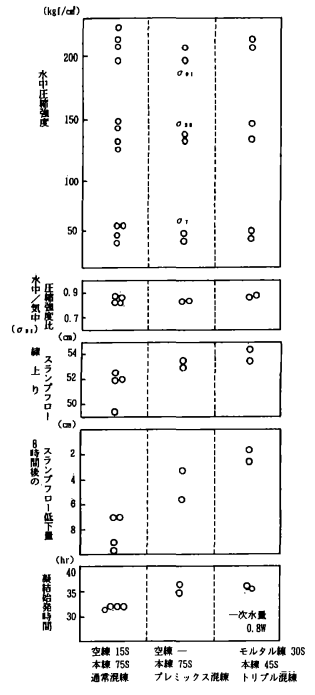

図一14＼cjkstart混練方法がコンクリートの性質に及ぼす影響

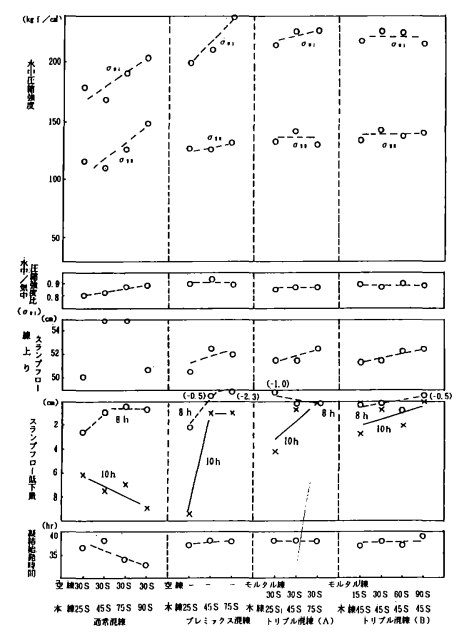

図一15 混練方法と本練り時間およびモルタル練り時間が コンクリートの性質に及ぼす影響

間とともに，凝結始発時間は短くなるが，プレミックス 混練, トリプル混練ではあまり変化しない.

・水中圧縮強度については, 通常混練およびプレミッ クス混練は, 練りまぜ時間が長くなると強度が増進する が, トリプル混練はあまり変わらない. 強度は,

通常混練くプレミックス混練ミトリプル混練 となっている.

・水中 $/$ 気中圧縮強度比については, 通常混練は, 練 りまぜ時間が長くなると大きくなるが，プレミックス， トリプル混練は練りまぜ時間にあまり依存していない.

以上，i），ii）に示すようにトリプル混練およびプ レミックス混練は, 通常混練に比較して短時間の練りま ぜで流動性の長時間保持が良いコンクリートが得られ 
る. また，トリプル混練で得られたコンクリートの品質 は安定しており，図一13に示すプレミックス混練で得 られるコンクリートのようにはばらつきがない。した がって,トリプル混練は他の練りまぜ方法に比較して短 時間で, 流動性の長時間保持の良い, 安定した品質のコ ンクリートが得られる。

(3) 練りまぜ水の分割投入がモルタルおよびコンク リートの性質に及ぼす影響を検討した実験(9)おび(11)の 結果を示した図一16 から以下のことがわかる.

・練上りスランプフローについては，モルタルは $W_{1} / W=0.5 \sim 0.8$, コンクリートは $W_{1} / W=0.8 \sim 1.0$ の近傍で練上りスランプフローが極小となっている.

・スランプフローの低下量については，モルタルは $W_{1} / W=0.75 \sim 1.0$ ，コンクリートは $W_{1} / W=0.75$ 0.9 の近傍で練上りスランプフローの低下量は極小とな る.

- 水中圧縮強度, 水中 /気中圧縮強度比は, モル夕ル, コンクリートともに0.5〜0.9の近傍で極大值となって

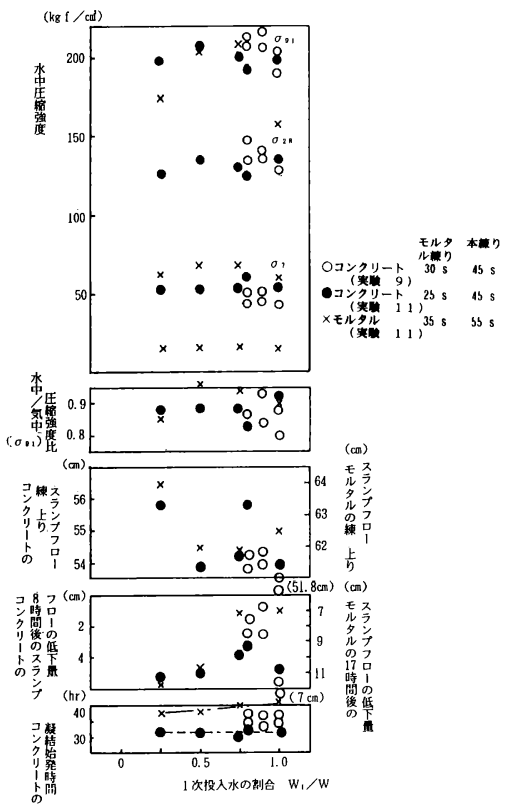

図一16 練りまぜ水の分割投入がモルタルコンクリートの性質 に及ぼす影響
いる.

・凝結始発時間は 1 次投入水量によらない.

練りまぜ水の分割投入効果は,モルタルを硬練りにし， 練りまぜ初期における練りまぜ効率を向上させ, 水中不 分離性混和剂-結合材-細骨材の接水時の分散効率を高め る意味があるものと推察される.

すなわち, 通常, 水中分離性コンクリートは単位水量 が多いため，モルタル分はきわめて軟練りであるためミ キサーの羽根がモル夕ルに与えるせん断摩擦力およびモ ルタル中の細骨材相互のせん断摩擦力が小さい.ここで 練りまぜ水を分割して投入するこをにより硬練りとし, せん断摩擦力を増すことができ，短時間に練りまぜがで きるものと思われる.

したがって,$W_{1} / W=0.25$ および 1.0 近傍では練り まぜ効率が不良のため, 練上りのスランプフローが不安 定で, スランプフローの長時間保持, 強度の発現が悪い ものと思われる.

\section{3. 本研究の実施例（明石海峡大橋 $3 \mathrm{P}$ 主塔基 礎水中コンクリート工事)}

\section{(1) 概 要}

本研究成果を実施工に適用した事例として, 明石海峡 大橋 $3 \mathrm{P}$ 主塔基礎水中コンクリート工事を紹介する.

主たる適用項目は以下の 2 点である。

(1) 流動性の長時間保持を得るために良質なコンク リート構成材料の選定

(2) 練りまぜ方式としてトリプル混練方式の採用

（2） 3P 主塔基礎水中コンクリート（水中不分離性 コンクリート) の施工法

明石海峡大橋は図一17 に示すように, 橋長 $3910 \mathrm{~m}$, 中央支間長 $1990 \mathrm{~m}, 3$ 径間 2 ヒンジ補剛トラス形式の 世界最長の吊橋である。

主塔基礎の施工法としては, 支持地盤まで掘削した後, 鋼ケーソンを設置し，中詰コンクリートを打設して基礎 を構築する設置ケーソン工法である.

淡路側の主塔基礎である $3 \mathrm{P}$ の水中コンクリートの 型枠となる鋼製ケーソンは図一18に示すように直径 78 $\mathrm{m}$, 高さ $62 \mathrm{~m}$ で, 2 重壁構造となっている. 内側の直 径 $54 \mathrm{~m}$ の内核部は, $\mathrm{TP}-57 \mathrm{~m}$ より $\mathrm{TP}-10 \mathrm{~m}$ まで約

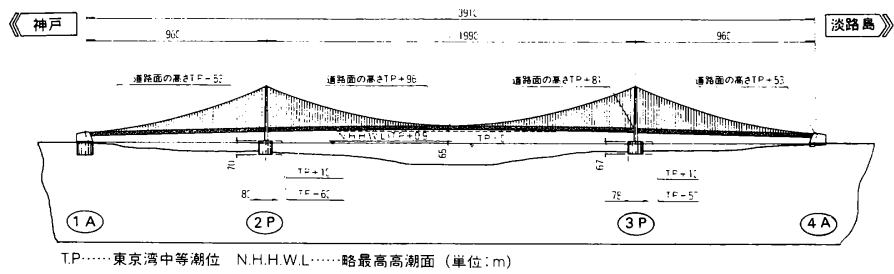

図一17 明石海峡大橋計画図 


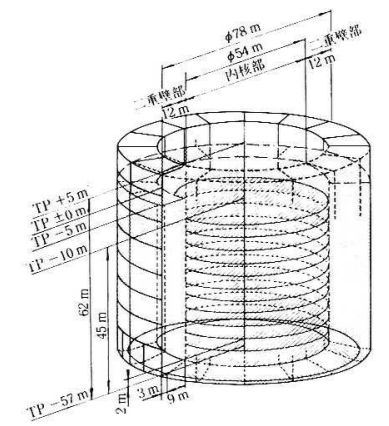

図一18 鋼ケーソン内打設ブロック割

11 万 $\mathrm{m}^{3}$ を 11 層に分けて打設した. 打設は 1 回当たり 約 $10000 \mathrm{~m}^{3}$ で, 3 昼夜連続打設した。第 1 層目は海底 地盤とのなじみ，ケーソン刃口下充填のため, 水中不分 離性モルタルを約 $2 \mathrm{~m}$ の高さまで打設した。 それ以降 の各層は水中不分離性コンクリートを打設した。コンク リートは 6 台のコンクリートポンプと分岐弁を使用し, ф200 の打設管 24 本で圧送した. 打設管 1 本当たりの 受持面積は約 $100 \mathrm{~m}^{2}$ である.コンクリートの硬化後, 無人の水中打継目処理機で打継目処理をした. 外側の二 重壁部は 16 区画に別れ， $\mathrm{TP}-57 \mathrm{~m}$ から $\mathrm{TP}-5 \mathrm{~m}$ まで 1 区画約 $8000 \mathrm{~m}^{3}$ を 6 本の打設管で一気に打設した. 総打設量は，約 $237000 \mathrm{~m}^{3}$ であった。

\section{（3）コンクリートの配合および品質}

コンクリート構成材料の品質として研究結果より, 結 合材の品質, 混合比率および骨材の品質がコンクリート の流動性に大きく影響することから以下の配慮をした。

(1) 結合材 流動性の長時間保持および発熱, 圧縮 強度を考慮に入れて三成分系混合セメントとし, 特に流 動性に大きな影響を与えるフライアッシュについては良を 質のものを使用.

(2) 細骨材 海砂亡し, 微粒分量が少なく, 粒度の 比較的大きく (FM 2.6 - 3.1) かつ, 粘土分が少ない ものを使用.

(3) 粗骨材標準粒度から少し粗めの骨材を使用.

\section{（4）水中コンクリートの施工設備}

水中コンクリートの施工設備は写真一1に示すように 大きく分けて 3 つに別れる.

a) コンクリートプラント台船「海神」

コンクリート材料の荷役, 貯蔵, コンクリートの製造, 圧送する設備を搭載した $25000 \mathrm{t}$ 台船で 8 本の千エーン によりケーソン東側に係留した。 表一5に主要艤装品を 示す。主な特徴を以下に列記する.

(1) 無補給打設能力約 $10000 \mathrm{~m}^{3}$, 最大製造能力約 $260 \mathrm{~m}^{3} / \mathrm{h}$ (水中不分離性コンクリート) を有する.

(2)トリプル混練により，流動性に優れた水中不分離 性コンクリートの製造が可能である.

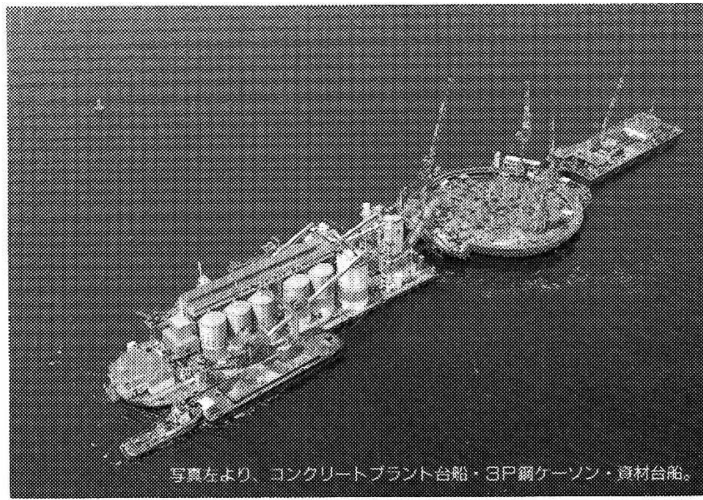

写真一1 資材台船-3P ケーソン-CP 台船の全景

\section{表一5 コンクリートプラント台船主要艤装品}

\begin{tabular}{|c|c|c|}
\hline $\begin{array}{l}4 \\
4 \\
4\end{array}$ & 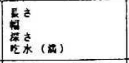 & $\begin{array}{r}150.0 \mathrm{~m} \\
10.0 \mathrm{~m} \\
8.5 \mathrm{~m} \\
6.5 \mathrm{~m} \\
\end{array}$ \\
\hline 变 & 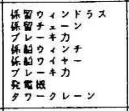 & 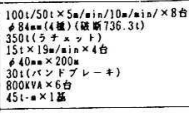 \\
\hline 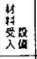 & 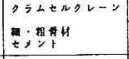 & 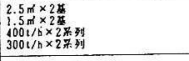 \\
\hline 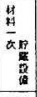 & 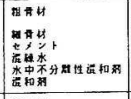 & 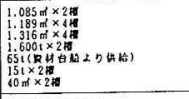 \\
\hline 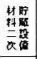 & 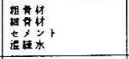 & 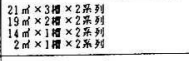 \\
\hline $\begin{array}{l}1 \\
0 \\
0 \\
0 \\
0\end{array}$ & 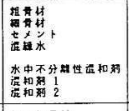 & 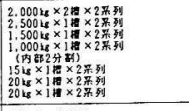 \\
\hline 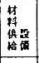 & 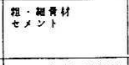 & 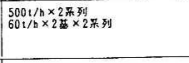 \\
\hline 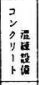 & 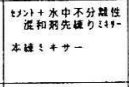 & 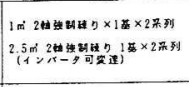 \\
\hline 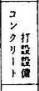 & 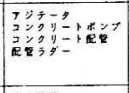 & 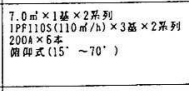 \\
\hline 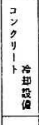 & 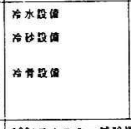 & 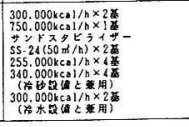 \\
\hline 贵 & \multicolumn{2}{|c|}{ 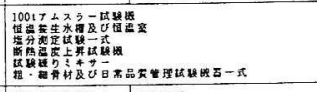 } \\
\hline 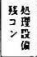 & 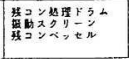 & 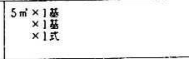 \\
\hline
\end{tabular}

（3）細骨材の表面水安定装置（サンドスタビライザ) の使用により，練上りコンクリートの品質が安定する.

(4) 冷水により骨材を冷却するプレクーリング設備を 使用し，コンクリートの練上り温度を $20^{\circ} \mathrm{C}$ 以下にする ことが可能.

(5) 明石海峡の $8 \mathrm{knot} の$ 急潮流でも作業可能な係留 設備を搭載.

b) $3 \mathrm{P}$ 鋼ケーソン上打設設備

3 基のタワークレーン $(400 \mathrm{tm})$, 中継用アジテータ $\left(40 \mathrm{~m}^{3}\right)$, および, コンクリート圧送用の 8 台のコンク 


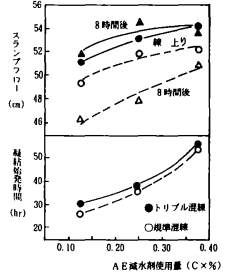

図一19 AE 減水㓮 (POZ, No. 70)

使用量とスランプフローお よび凝結始発時間の関係

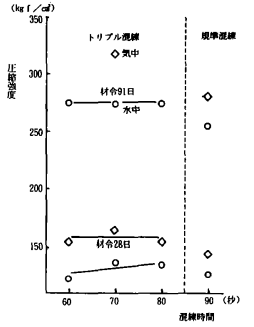

図一20 練りまぜ方法, 練りまぜ時間と 圧縮強度の関係

リートポンプ (予備 2 台を含む), $\phi 200$ 圧送管, 分岐弁, 打設管, 打設管先端監視用テレビカメラ, 打設管引揚装 置, 打継目処理設備, 濁水処理設備を設置した.

c) 資材台船

海水の淡水化装置, 清水, 濁水の貯蔵, 濁水処理設備, 資機材の貯蔵設備を有する $12000 \mathrm{t}$ 台船で 8 本のチェー ンによりケーソン西側に係留した.

\section{（5）水中不分離性コンクリートの品質}

a) 試 験 練

本工事に先立ち, 平成元年 12 月に $600 \mathrm{~m}^{3}$ の試験打設 を行いコンクリートの品質の確認を行った。この試験で 規準混練（空練り $20 \mathrm{~s}$, 本練り $70 \mathrm{~s}$ ) とトリプル混練（モ ルタル練り $25 \mathrm{~s}$, 本練り $45 \mathrm{~s})$ の比較を行った。この結 果は以下に述べるとおりであり, トリプル混練が在来の 空練り方式（規準混練）に比較して短い練りまぜ時間に もかかわらず優れた品質が得られる事が確認できた。

(1) フレッシュコンクリートの性状

$\mathrm{AE}$ 減水剂量を変化させ，スランプフローの経時変化 之凝結始発時間を調查した。図一19 から, 凝結始発時 間は練りまぜ方法による差異はみられないが，スランプ フローの保持はトリプル混練が良い結果を得た。

(2) 強 度

練りまぜ時間を変えて強度の比較を行ったのが, 図一 20 である.トリプル混練の方が若干強度が高い。

b) 本 工 事

平成 2 年 4 月 22 日 24 日に打設した，第 7 回打設時 の練上り品質状況を図一 21 に示す。サンドスタビライ ザーを使用することで，砂の表面水率は処理前平均 4.8 \%，標準偏差 $0.74 \%$ から処理後はおのおの $3.3 \%$, $0.18 \%$ と安定している. コンクリートのスランプフロー は練り平均 $53.8 \mathrm{~cm}$, 標準偏差 $0.70 \mathrm{~cm}$ から, 8 時間後 はおのおの $51.7 \mathrm{~cm}, 0.97 \mathrm{~cm}$ と安定しており, 本研究 の適用による良質なコンクリート材料の採用，トリプル 混練の採用に合わせて, サンドスタビライザーの使用が 好結果をもたらしたものと思われる.

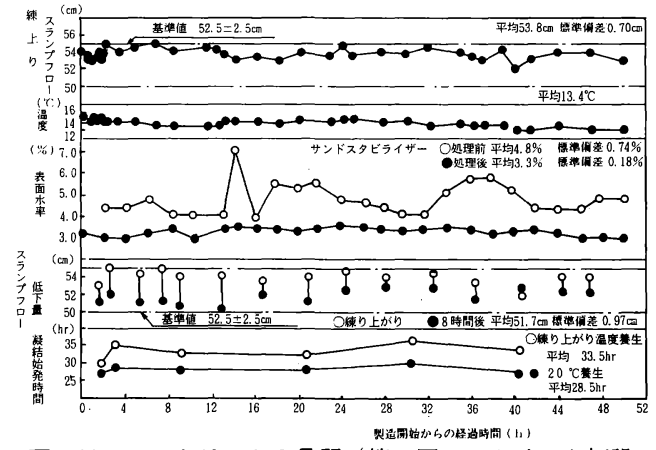

図一21 コンクリートの品質（第 7 回コンクリート打設, H 2.4.22 24)

\section{4. あとがき}

この研究の成果を以下に列記する.

（1）水中不分離性コンクリートの流動性の長時間保 持および，凝結特性は，コンクリートの構成材料である フライアッシュ，細骨材の品質に特に影響を受ける.

（2）練りまぜ方法の違いで水中不分離性コンクリー 卜の品質が変化し, 今回提案したトリプル混練方式では, 短い練りまぜ時間で流動性の良い安定したコンクリート が得られた。

今後，ますます，この種のコンクリートが時代の要請 とともに使用されていくものと思われる，われわれの研 究がその一助になれば幸いである。

\section{参 考 文 献}

1) 田沢ほか：骨材および混和剤の種別が水中不分離性コン クリートの流動性および強度に及ぼす影響, 水中不分離 性コンクリートに関するシンポジウム論文集, 1990 年 8 月.

2）松井ほか：特殊水中コンクリートの製造方法に関する㬰 験, 土木学会第 42 回年次学術講演会, 1987 年 9 月.

3）宮野ほか：練りまぜ手順が特殊水中コンクリートの特性 に及ぼす影響，土木学会第 42 回年次学術講演会，1987 年 9 月.

4）大友・松岡・中川・中平：特殊水中コンクリートの凝結 特性に及ぼす材料の影響に関する研究，コンクリート工 学年次論文報告集 11-1，1989 年.

5）中川・大友・中平・松岡：低発熱高流動性特殊水中コン クリートに関する研究, コンクリート工学論文集, 第 1 号, 第 1 巻, 1990 年 1 月.

6）坂本・平野・中川・山田・白木：コンクリートプラント 台船「海神」に上る明石海峡大橋 $3 \mathrm{P}$ 主塔基礎水中コン クリートの施工，建設の機械化，1990 年 6 月.

7）中川・大友・中平・松岡：水中不分離性コンクリートの 品質, 特に分離抵抗性之凝結, 流動性の長時間保持に関 する研究, 水中不分離性コンクリートに関するシンポジ ウム論文集, 1990 年 8 月.

(1990.12.10・受付) 